\title{
PERI-OPERATIVE NUTRITION FOR EXTREMELY PRETERM INFANTS UNDERGOING SURGICAL TREATMENT FOR PDA
}

V. Westin ${ }^{1}$, E. Stoltz Sjöström ${ }^{2}$, A. Gudmundsdottir ${ }^{1}$, E. Engström ${ }^{3}$, V. Fellman ${ }^{4}$, F. Ahlsson ${ }^{5}$, E. Olhager ${ }^{6}$, E. Lindberg ${ }^{6}$, A.K. Edstedt-Bonamy ${ }^{1}$, M. Domellöf ${ }^{2}$, M. Norman ${ }^{1}$

${ }^{1}$ Karolinska Institute, Stockholm, ${ }^{2}$ Umeå University, Umeå, ${ }^{3}$ Gothenburg University, Gothenburg, ${ }^{4}$ Lund University, Lund, ${ }^{5}$ Uppsala University, Uppsala, ${ }^{6}$ Linköping University, Linköping, Sweden

Background and aim: In Sweden, 24\% of extremely preterm infants are surgically treated for patent ductus arteriosus (PDA). The aim of this study was to evaluate the peri-operative nutrition.

Methods: Population-based cohort ${ }^{1,2}$ of 118 extremely preterm infants (gestational age $<27$ weeks, birth weight $719 \pm 161 \mathrm{~g}[\mathrm{mean} \pm \mathrm{SD}], 63(53 \%)$ boys, 19 multiplets) treated with surgical ligation of PDA (mean postnatal age 22[range 3-82] days) and surviving to 1 year-of-age. Nutrition was collected from hospital charts (24 infants with incomplete records). Daily intakes of total enteral and parenteral nutrients, including blood products, were entered into a computer based tool for nutrition analysis. Provision of energy, protein, fat and carbohydrate was calculated three days before (day-3), on the day of surgery (day0) and three days after surgery $($ day +3$)$. Data were compared to minimal requirements according to international recommendations. ${ }^{3}$

Results: The fluid volume day0 was $166 \pm 44 \mathrm{ml} / \mathrm{kg} / \mathrm{d}$ and was the same as day-3(165 \pm 31$)$ and day $+3(164 \pm 36$, mean \pm SD).

\begin{tabular}{|l|l|l|l|l||}
\hline $\begin{array}{c}\text { Nutrients, \% of } \\
\text { minimal } \\
\text { req.(95\%CI) }\end{array}$ & \multicolumn{1}{|c|}{ Day $\mathbf{- 3}$} & Day 0 & Day +3 & Minimal req3 \\
\hline Energy & $83-91$ & $62-70$ & $83-89$ & $110 \mathrm{kcal} / \mathrm{kg} / \mathrm{d}$ \\
\hline Protein & $73-81$ & $68-80$ & $71-77$ & $4.0 \mathrm{~g} / \mathrm{kg} / \mathrm{d}$ \\
\hline Fat & $82-98$ & $45-55$ & $85-99$ & $4.8 \mathrm{~g} / \mathrm{kg} / \mathrm{d}$ \\
\hline Carbohydrate & $95-105$ & $111-121$ & $96-104$ & $12 \mathrm{~g} / 100 \mathrm{kcal}$ \\
\hline
\end{tabular}

[table1]

Conclusions: Peri-operative nutrition for extremely preterm infants undergoing surgical treatment for PDA is suboptimal and needs to be improved. The significance of malnutrition for outcome after PDA surgery is still unclear and will be investigated.

1. JAMA 2009;301(21):2225-2233

2. Acta Paediatr 2010:99:978-992

3. J Pediatr Gastroenterol Nutr 2010;50;1-9 